core oil duct and finally the 'gas pressure' three phase cable. Operating experience is still too scanty to allow definite conclusions to be drawn as to their relative merits. Hitherto they have only been used in situations like central London which preclude the use of overhead lines.

\section{Kaiser Wilhelm Gesellschaft}

NEARLx forty pages of parts 21-23 of Die Naturwissenschaften, 1933, are devoted to an account of the activities of the Kaiser Wilhelm Gesellschaft during the period April 1932 until March 1933. The financial stringency has been felt during the year just as much as it was last year, and research work has had to be cut down to a minimum in several departments. It has also affected the membership, which has fallen from 829 to 786. At the headquarters-Harnack House-five evening lectures on scientific subjects and five of a popular character have been delivered, and four have been given in other towns of Germany. Many members of the staff have also been invited to address scientific gatherings outside Germany, and several have accepted permanent posts in the United States, Switzerland and Sweden. 230 foreign men of science have during the year put up for short periods at Harnack House, as compared with 242 the previous year, and 190 meetings of other societies have been accommodated as against 212 during the previous year. 445 additions have been made during the year to the library. Information of this general nature is followed by a short account of the work done in each section of the Association and a list of the publications emanating from it.

\section{History of Fever Treatment in London}

Is an article entitled "Willan and Bateman on Fevers" in the October issue of the British Journal of Dermatology, Dr. J. D. Rolleston maintains that Robert Willan (1757-1812), in addition to being the father of British dermatology, was also a pioneer in epidemiology at a time when infectious diseases were more prevalent and severe than at the present day. In addition to his work on vaccination, of which he was a warm advocate, and his observations on scarlet fever and measles, by his work on cutaneous diseases and his reports on diseases in London in 1796-1800, Willan played a prominent part in the establishment of the first fever hospital in London. Apart from the smallpox hospital at King's Cross, which had been in existence since 1746, at the beginning of the nineteenth century, London did not possess a fever hospital of any kind, and it was mainly in consequence of the prevalence of typhus fever at the end of the eighteenth and beginning of the nineteenth centuries that hospitals under the name of 'houses of recovery' were established throughout the country. They were first opened at Chester, Manchester, Liverpool, Norwich, Hull, Dublin, Cork and Waterford, and later, owing to the advocacy of Willan and other distinguished physicians, the example set by the provinces was followed by London. In 1802 the Society for Bettering the Condition of the Poor fitted up in Gray's Inn
Road a private house as a hospital for poor patients, to which Willan was appointed the first physician, and was succeeded two years later by Bateman, who held the post for twelve years.

\section{Need for Flexibility in International Agreements}

Mr. W. WATkin Davies, in an article on "Justice in International Affairs" published in the Hibbert Journal, 31, No. 4, argues that justice in the international sphere, based on treaties and conventions, is not adequate, and the machinery which enforces it is likely to develop into the most abominable tyranny, if it is not supplemented by something else. In a world where changes occur in different countries at different times, it is folly on the part of statesmen to make peace settlements which they declare to be final, without at the same time providing for future prevention of political and economic grievances. Changed circumstances give rise to legitimate national aspirations. Mr. Davies gives examples from past and from contemporary history to show how changes in population render geographical boundaries unsatisfactory. Remedies other than acquisition of new territory, such as increased efficiency in production or colonisation, are of little avail at present because of the prevailing economic nationalism. There remains one way out: for nations sooner or later to take their fate in their own hands and break the law, by resorting to war. If economic and political hostility is to be avoided, flexibility must be introduced into our international system. An institution must be set up-it already exists in a very crude form in the League of Nations - the task of which will be to revise treaties from time to time, and to readjust national boundaries, redistribute economic resources, regulate migration in the interest of the world as a whole, and generally to reconsider every reasonable national aspiration. The way is indicated by Article XIX of the Covenant.

\section{Man and Machine}

IN the Quarterly Review for October 1933, Mr. W. F. Watson contributes an interesting article on "The Machine and its Purpose" in which he combats the view so often taken for granted that machinery involves dull, monotonous work which 'dehumanises' the worker, robs him of interest in his job and crushes individuality. The machine, he admits, continually encroaches on the sphere of certain crafts and changes the form of others, but at the same time it has created new crafts involving a high degree of skill, initiative and individuality, such as that of jig, tool, fixture, mould, die and gauge makers. Passing on to consider the machine operator, he argues that a person who controls a machine with ease, skill and precision is the master of that machine, not its slave. The man who is master of his job, no matter how elementary it be, must of necessity take some interest in it. Moreover, modern industrial investigations such as those of the National Institute of Industrial Psychology have led to an appreciation of the importance of the 'human factor' and have shown how to counteract the effects of monotony. 